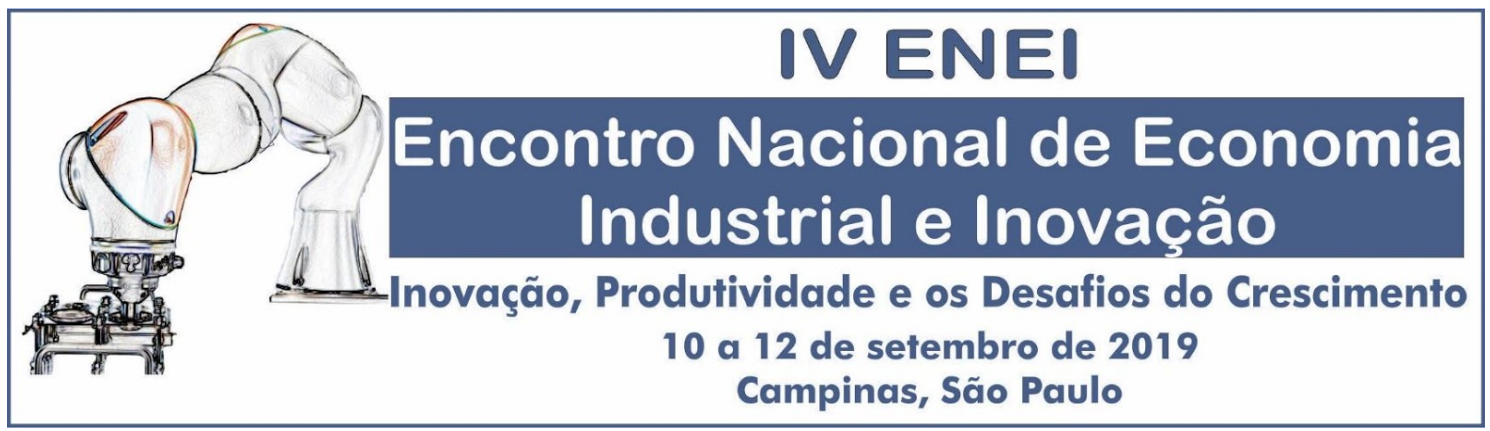

Research infrastructures in developing countries:

The Brazilian case

\author{
Thiago Caliari *, Márcia Siqueira Rapini **, Tulio Chiarini *** \\ * Instituto Tecnológico de Aeronáutica (ITA), ** Cedeplar/UFMG, \\ *** Instituto Nacional de Tecnologia (INT)
}

\begin{abstract}
High quality research infrastructure is required to conduct S\&T activities which may help to address national challenges and contribute to innovation processes. Given this, an exhaustive survey conducted by the Brazilian Institute of Applied Economic Research (Instituto de Pesquisa Economica Aplicada - IPEA) was undertaken to diagnose the current research infrastructure situation in Brazil. Using this data, the present paper provides information that allows us to yield new insights based on the peculiarities of the research infrastructure in Brazil, complementing the studies already present in the literature. Two econometric models - Logit and Probit - were used to "measure" the relative modernity of the research infrastructure in the country. We test the impact of variables frequently present in innovation studies - lab size, S\&T production scale and scope, lab longevity and interactions with other labs and profit-seeking firms. We found that scaling up, modernizing and interacting with other agents of the Innovation System increase the chances of a research infrastructure to be considered "advanced".
\end{abstract}

Key-words: research infrastructure, innovation system, S\&T public policy, Brazil

\begin{abstract}
Resumo
Infraestruturas científicas de alta qualidade são importantes para a condução de atividades de Ciência e Tecnologia que podem fomentar e contribuir em processos inovativos de interesse nacional. Dado isso, uma exaustiva pesquisa foi conduzida pelo IPEA para diagnosticar a situação atual das infraestruturas de pesquisa no Brasil. Utilizando esses dados, o presente trabalho apresenta informações que permitem verificar novos insights baseados nas peculiaridades dessas infraestruturas, complementando estudos já presentes na literatura da área. Foram propostos modelos econométricos - Logit e Probit - para mensurar a capacidade relativa das infraestruturas, testando o impacto de variáveis frequentemente presentes em estudos de inovação: escala e escopo da produção científica e tecnológica, longevidade, interação com demais agentes, regionalidade, entre outros. Foi constatado que maior escala, modernização e interação com agentes do Sistema de Inovação aumentam as chances de uma infraestrutura de pesquisa ser considerada avançada.
\end{abstract}

Palavras-chave: infraestrutura de pesquisa, sistema de inovação, políticas de C\&T, Brasil. Área ABEIN: 6.2 Políticas de Ciência, Tecnologia e Inovação

JEL: O3 


\section{Research infrastructures in developing countries: The Brazilian case}

\section{Introduction}

Influenced by the primary studies done by F. List ${ }^{1}$ and J. Schumpeter ${ }^{2}$, C. Freeman and his colleagues (Lundvall, 1992; Nelson, 1993; Kim, 1997; Freeman, 2004; Lee, 2019) have been suggesting for the past decades that public investments in science and technology (S\&T) are crucial for successful economic development. Therefore, high quality research infrastructure is required to conduct S\&T activities which may help to address national challenges and contribute to innovation processes.

Within the National Systems of Innovation (NSI) framework, research infrastructures are crucial loci for S\&T advances and policy makers have been influenced by this perspective. Therefore, national efforts have been undertaken to map the country's research infrastructures such as the case of the Survey of Science and Engineering Research Facilities, conducted biennially by the U.S. National Science Foundation to collect data on the amount, construction, repair, renovation, and funding of the American research infrastructure. Other national reports have also given attention to the research infrastructure; for example, Australia (Strategic Roadmap for Australian Research Infrastructure), Germany (HelmholtzRoadmap for Research Infrastructures) and Finland (Finnish Research Infrastructure Survey and Roadmap).

If there are many fruitful surveys and reports on the research infrastructures of developed countries, the same cannot be said about developing countries. Even though many developing countries have their research infrastructures established, there are little national efforts to evaluate them continuously. In China, for instance, a research devoted to make a systematic evaluation of the scientific effects of its research infrastructure showed that they are relevant to the acquisition of new knowledge, and contribute to the proliferation of competitive scientific organizations and scientific talents (Qiao et al., 2016).

In what regards Brazil, which is recognized for having a non despicable scientific community and considered as an emerging power in research ${ }^{3}$, just very recently an exhaustive survey was undertaken to diagnose the current research infrastructure situation in the country. The survey was conducted by the Institute of Applied Economic Research (Instituto de Pesquisa Econômica Aplicada - IPEA) and the data collected allows $n$ possible analysis. De Negri and Squeff (2016) organized the studies which were published in 2016 and they make a comprehensive view of the features of the Brazilian research infrastructure. As a consequence we can recognize there are many contrasting labs in operation simultaneously and their size, S\&T production scale and scope, longevity and interactions with other labs and firms are just some possible distinguishing characteristics we can list to perceive the existence of a research infrastructure constellation in the country.

In line with the studies organized by De Negri and Squeff (2016) and using the same database, our main objective is to provide information that allow us to yield new insights based on the peculiarities of the research infrastructure in Brazil, complementing the studies already present in the literature. Before we proceed, we make an important caveat: the term "research infrastructure" is not uniformly and globally defined and for our study it means facilities, resources and related services used by Brazilian scientific community to conduct their researches in their respective knowledge fields and covers major scientific laboratories; research ships or floating laboratories; and plants or pilot plants from universities and research institutes. With that definition in mind, we propose econometric models - Logit and Probit - to "measure" the relative modernity of the research infrastructure in the country according to a subjective perception of its modernity (i.e., advanced, sufficient and insufficient labs). We aim to investigate if infrastructure characteristics (lab size, scale and scope, longevity, interactions with other labs and firms and location affect) impact labs relative modernity compared to research infrastructures worldwide (according to research leaders' perception). In a broad context, we expect to contribute highlighting features of research

\footnotetext{
"National System of Political Economy".

"Theory of Economic Development" and "Capitalism, Socialism, and Democracy".

https://www.economist.com/the-americas/2011/01/06/go-south-young-scientist
} 
infrastructures in developing countries, in order to provide information for public policies.

To fulfill our goal, we organized the paper as follows. In section 2, we make a concise introduction on the role of science and research infrastructures to innovation in developing countries. In section 3, we make a brief review of the research infrastructure in Brazil. We present the database and the econometric models in section 4. After we make a discussion of the results found and finally we conclude the paper with some final remarks and policy recommendations.

\section{The role of science and research infrastructures to innovation in developing countries}

The concept of National Systems of Innovation (NSI) developed by some scholars (Nelson, 1993; Lundvall, 1992; Freeman, 1992) explicitly states that a firm's innovative processes result from knowledge development which is a collective action and take place both within and outside the firm. Therefore, institutional structures to support the development of technological activities are fundamental in order to consolidate a NSI.

A growing number of studies have focused on the application of the NSI framework for development issues in less developed countries (Lundvall et al., 2009). These studies point out the importance to "understand learning and innovation efforts in all kinds of organizations, even those far behind the technological frontier" (Cassiolato \& Soares, 2015, p. 20) Moreover, the relevant knowledge could not be directly related to formal education and/or S\&T systems.

There is an extensive literature that describes the roles of science to technological progress and innovation (Pavitt, 1991; Brooks, 1994; Salter \& Martin, 2001) and we can summarize them as follows:

a) science is a source of new technological ideas, it enhances the knowledge stock;

b) science is a source of new research instruments and methodologies;

c) science could solve technological and innovative problems;

d) science is a source of qualified personnel;

e) science is the source of spin-offs and startups firms, for some specific scientific areas.

In developing countries science could have different roles as they face negative characteristics such as social problems and low levels of private R\&D activities, some have existing scientific infrastructures but with few areas reaching international levels, poor articulation and interaction among actors and low absorptive capacity. For those countries, science and research infrastructures may contribute significantly to the country's economic development and growth through technological and innovative efforts (Bernardes \& Albuquerque, 2003; Ribeiro et al., 2010). An effective research infrastructure in a developing country can produce scientific results able to play a sort of "antenna role" or a sort of "focusing device" - i.e., "an instrument to focus the direction of technological progress" (Rosenberg, 1976). In this regard, the existence of a research infrastructure signals the viable scientific and technological areas of relative success, given the domestic features and the international conjuncture. Besides, as pointed out by Foray (2010), the creation of capabilities in scientific research are frequently correlated to government action in less developed countries, since "neither multinational corporations' affiliates nor local firms have the incentives and/or capabilities to do this" (Foray, 2010, p. 102).

A second contribution of science and research infrastructures is the support of industrial development. Unlike their role played in developed countries as a source of "technological opportunities" (Klevorick et al., 1995) in a developing country, they contribute to identifying existing international opportunities. Among them, they could indicate the possibilities of entry into strategic industries and also could reduce the cost associated with it (Perez \& Soete, 1988).

A third contribution lies in the advances in S\&T towards health systems and, consequently, towards social development and economic growth (Acharya, 2007). A substantial and dynamic research infrastructure is necessary to solve national health issues. The fourth is linked to the progress in agriculture as technology should be suited to countries own environmental conditions (Mazzoleni \& Nelson, 2005). The fifth contribution of science and research infrastructures is the need to adapt the technologies from 
developed countries to local needs (Kim, 1997; Mazzoleni \& Nelson, 2005) as a lot of knowledge is necessary to select, buy, transform and use technology (Cassiolato \& Soares, 2015).

Besides the studies presented previously that focus on the contribution of science and research infrastructures, a great deal of work has been conducted to investigate some features which impact the excellence of research infrastructures. Some of them highlight the importance of scale and scope at research (Vonortas et al., 2011; Vonortas, 2009), educational issues (Johnes \& Johnes, 2016; Koshal \& Koshal, 1999; Olivares \& Wetzel, 2011), and scientific levels (Cohen, 1981; 1991; Cockburn \& Henderson, 2001; Hernandez-Villafuerte et al, 2017, Kannebley et al, 2018). Results are not conclusive and they point to a mix of distinct results.

Some studies confirm the linear positive economies of scale (Cohen, 1981; Cockburn \& Henderson, 2001) and/or economies of scope (Kannebley et al, 2018), while others present this positivity until some specific lab size. An inverse U-shaped relation is seen in the results presented by Vonortas et al. (2011) and some empirical studies demonstrated by Hernandez-Villafuerte et al (2017) for funded biomedical and health research, or a well-marked maxima of publication rates (Qurashi, 1984), which may point the risks of both "too large" and "too small" research projects.

Other studies show that large-scale research infrastructures are more able to involve many scientists and technicians increasing the possibilities of cooperation (Lozano et al., 2013; Del Bo et al., 2016; D'Ippolito \& Rüling, 2019), generating economic spillovers, particularly through learning (Foray, 2004). Despite the inconclusiveness of the topic, public policies have been created to strengthen research infrastructures and incentivize their growth (EC, 2010; OECD, 2010).

Additionally, we can emphasize the relevance of technological improvements on scientific developments (Kline; Rosenberg, 1986), the possible existence of a learning curve (Ritter; Schooler, 2002) as well as cooperation with scientific institutions and profit-seeking firms (Cohen et al., 2002; Wright, Birley \& Mosey, 2004; Sjoo \& Hellstrom, 2019; Klevorick et al., 1995; Mansfield, 1991).

Last but not least, regions are important for knowledge creation and learning, therefore regions' research structure may generate feedbacks on the regions' economic system (Florida, 1995). This process is related to Myrdal's circular cumulative causation (Myrdal, 1960) where inequalities are reinforced by the system; in this view, strong economies are associated with strong regional innovation systems in a selfreinforcement process (Cooke, 2001; Santos \& Caliari, 2012).

All those features will be tested in the empirical models proposed in this paper.

\section{$3 \quad$ Research infrastructures in Brazil: a brief review}

Even if some public universities and research institutes were founded in the 1920s and 1930s, the Brazilian university system is relatively recent and it has been in existence for less than a century (Mello et al., 2009; Maculan \& Mello, 2009). Compared to other Latin American countries, Brazil started relatively late on establishing universities (Suzigan \& Albuquerque, 2011). While in some Latin American countries the first universities were established in the 16th century (as in Mexico and Peru) or in the 17th century (as in Bolivia), in Brazil colleges of medicine, law or engineering emerged only in the first half of the 19th century (Mello et al., 2009) and the first university was established solely in 1920, in Rio de Janeiro, by the Federal Government. In 1934 the state of São Paulo created its own university (Maculan; Mello, 2009), namely Universidade de São Paulo (USP), which was Brazil's first fully-fledged university (Schwartzman, 1991).

Notwithstanding that, we can assure that the Brazilian research infrastructure was established by the 1950s with the intensification of the establishment of a great deal of public research institutes (such as the Brazilian Center for Research in Physics ${ }^{4}$ and the National Nuclear Energy Commission ${ }^{5}$ ) and other public universities throughout the country (Schwartzman, 1991). The period also witnessed the creation of agencies to foster the scientific research as the National Council for Scientific and Technological

Centro Brasileiro de Pesquisas Físicas - CBPF.

Comissão Nacional de Energia Nuclear-CNEN. 
Development ${ }^{6}$ and the Coordination for the Improvement of Higher Level Personnel ${ }^{7}$ to build human resources' capabilities in research and to finance scientific research projects. On the same track, the Finance Agency for Studies and Projects ${ }^{8}$ was designed to finance S\&T and innovation in firms, universities and research institutes. (Suzigan; Albuquerque, 2011). Together with the Foundations for Supporting Research ${ }^{9}$, they form today the core of S\&T public funding agencies in the country, with 29 institutions (Table 1).

We can currently identify in Brazil 197 universities of which 55\% are public institutions (Table 1). According to many studies, most of the scientific activities in the country presently are carried out by federally and state funded universities (Albuquerque et al., 2002; Chiarini et al., 2013). Public research institutes also play a crucial role in the production of science in the country (Chiarini et al., 2013), and there are 64 of them spread throughout Brazil today. They are mainly financed by federal funds and most of them are directly linked to the Ministry of Health, Ministry of Science \& Technology and Ministry of Defense.

Table 1 - Number of universities, public research institutes and S\&T public funding agencies

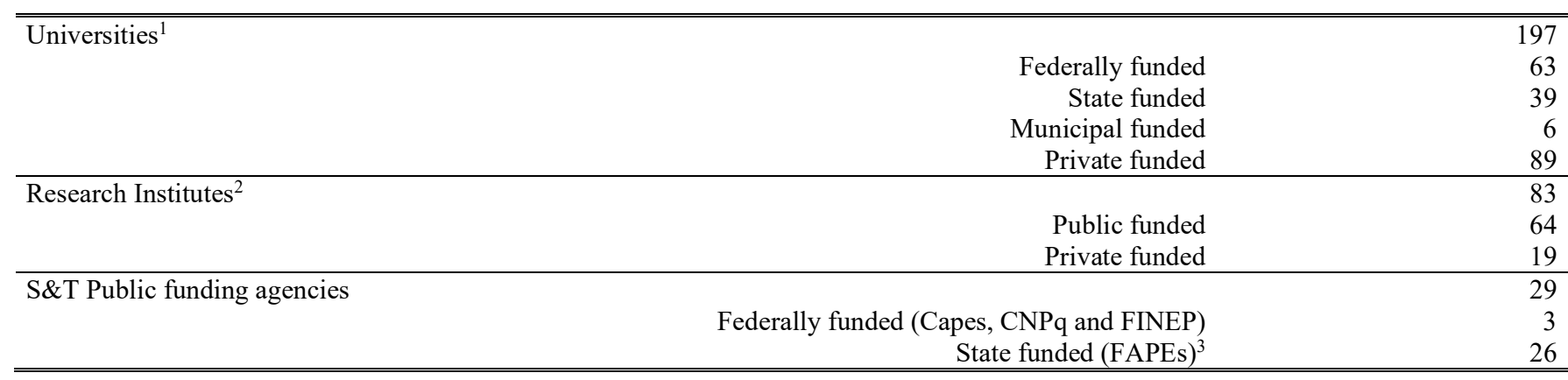

Source: Authors' own elaboration, data sourced from $\left({ }^{1}\right)$ Instituto Nacional de Estudos e Pesquisas Educadionais Anísio Teixeira (INEP) for 2016, $\left({ }^{2}\right)$ Associação Nacional de Pesquisa e Desenvolvimento das Empresas Inovadoras (ANPEI) and $\left(^{3}\right)$ Conselho Nacional das Fundações Estaduais de Amparo à Pesquisa (CONFAP).

The establishment of the Brazilian research infrastructure was strongly influenced by the linear model of innovation (Guimarães, 2002) which, until very recently, inspired the scientific development presented in the National Plans. In 2000's, for instance, the former Brazilian Ministry of Science \& Technology ${ }^{10}$ set up a national policy based on the Sector-Specific Funds and the parliament promulgated the so-called "Innovation Law" in order to stimulate technological innovations by modernizing the regulatory environment, providing training focused on innovative activities and viewing the formulation of a S\&T policy as a development strategy.

Among the many sectorial funds managed by the Finance Agency for Studies and Projects, the Infrastructure Fund (CT-Infra) was designed to enable the modernization and expansion of research infrastructure in public research institutes and universities, by installing new plants and renovating labs. From 2001 (when the law was approved) to 2010, CT-Infra enabled the investment of more than USD 400 million in implementing and updating the research infrastructures in public institutions, what probably helped the Brazilian performance in producing internationally relevant scientific results (De Negri et al., 2013).

\section{$4 \quad$ Methodology}

\subsection{Database}

Conselho Nacional de Desenvolvimento Científico e Tecnológico - CNPq.

Coordenação de Aperfeiçoamento de Pessoal de Nível Superior - Capes.

Financiadora de Estudos e Projetos - FINEP.

Fundações de Amparo à Pesquisa - FAPEs

10 Ministério da Ciência e Tecnologia - MCT and today Ministério da Ciência, Tecnologia, Inovações e Comunicações MCTIC. 
The database used in this paper was firstly presented by De Negri and Squeff (2016). Their study, regarding the Brazilian research infrastructure, was pioneered in the country and it was inspired by researches done for relatively more mature NSIs. The questionnaire designed by De Negri and Squeff (2016) had the following objectives:

a) Evaluate the conditions of research infrastructures in Brazil, in order to identify main bottlenecks and lacks of investment;

b) Provide detailed information for policy makers, guiding public investments;

c) Provide empirical elements for evaluating and monitoring public policies aimed at expand research infrastructures;

d) Provide information for scientific communities and profit firms in order to enable university-firm relations;

e) Provide a relevant instrument for the research institutions themselves;

f) Provide a dynamic database that allows systematic monitoring as well as reports about the evolution of the Brazilian research infrastructure.

Considering the relevant specificities of the study, the population of interest was defined as "research infrastructures". The term "research infrastructure" is not uniformly and globally defined and for us it means facilities, resources and related services used by Brazilian scientific community to conduct their researches in their respective knowledge fields (agricultural sciences, biologic sciences, earth and exact sciences, health sciences and engineering) and covers major scientific laboratories; research ships or floating laboratories; and plants or pilot plants. Such infrastructure is located in universities and/or research institutions (public and private ones). Moreover, research infrastructures included laboratories; research ship or floating laboratories; and plants or pilot plants ${ }^{11}$.

After several methodological procedures ${ }^{12}$ to find those infrastructures countrywide, the researchers were able to identify 4,857 infrastructures located in 185 universities and research institutes. All of them received the invitation to answer the questionnaire proposed by De Negri and Squeff (2016), however, some institutions did not respond to the questions regarding the number of labs, so database does not represent the totality of research infrastructure in Brazil ${ }^{13}$.

Despite that, the response rate achieved is quite high: $36 \%$ of the research infrastructures in $70 \%$ of the institutions answered the questionnaire. Research infrastructure type and knowledge field of each one is presented in Table 2.

Table 2 - Number of respondents according to research infrastructure type and knowledge field

\begin{tabular}{l|r|r}
\hline \hline \multicolumn{1}{|c|}{ Research infrastructure type } & Number & $\%$ \\
\hline Laboratory & 1,694 & 1 \\
Research ship or floating laboratory & 98.8 \\
Plant or pilot plant & 0.1 \\
\hline \multicolumn{1}{c|c}{ Knowledge field } & Number* & 1.1 \\
\hline Agricultural sciences & 277 & $\%$ \\
Biologic sciences & 459 & 13.3 \\
Earth and exact sciences & 545 & 22.1 \\
Health sciences & 143 & 26.2 \\
Engineering & 658 & 6.9 \\
\hline \hline
\end{tabular}

Source: Authors' own elaboration. Note: $\left(^{*}\right)$ The sum of knowledge field is superior than 1,715 once it was allowed to research leaders to select one or more in the questionnaire.

The research infrastructures in Brazil are predominantly laboratories $(98.8 \%)$ as presented in Table 2 , mainly focused in engineering (31.6\%), earth and exact sciences $(26.2 \%)$ and biologic sciences $(22.1 \%)$.

11 For simplicity, "research infrastructure" is exchangebely called "lab" throughout this paper and both have the same meaning for us.

12 Those methodological procedures were described by De Negri and Squeff (2016).

13 As argued by De Negri and Squeff (2016), it not seems a limitation since Crow and Bozzeman (1998) were able to identify approximately 15,000 infrastructures in United States. 
Moreover, $66.6 \%$ of research infrastructures are concentrated in only 16 universities/research institutes. We can highlight the Brazilian Agricultural Research Corporation ${ }^{14}(16.9 \%)$, University of São Paulo - USP (9.9\%), Federal University of Rio de Janeiro - UFRJ (6.9\%), State University of Campinas - Unicamp (5.4\%), University of Brasília - UnB (4.8\%), and institutions of the Brazilian Air Force ${ }^{15}(6.8 \%)$.

In the structured questionnaire prepared for the research, De Negri and Squeff (2016) asked the research leaders their perception of the relative maturity of their research infrastructures. The answers were classified as follows:

1) Advanced and compatible with the best research infrastructures worldwide;

2) Advanced for Brazilian standards, however not compatible with the best research infrastructures worldwide;

3) Adequate and compatible with other domestic research infrastructures;

4) Insufficient in relation to other research infrastructures in Brazil;

5) Not able to evaluate.

For statistical purposes and simplicity, we used a more synthetic procedure, establishing only three possible classifications ${ }^{16}$ :

a) Advanced research infrastructure: infrastructures classified as 1 and 2;

b) Sufficient research infrastructure: infrastructures classified as 3;

c) Insufficient research infrastructure: infrastructures classified as 4 .

The final database (after treatments for inconsistencies) is composed of 1,715 research infrastructures, distributed as follows: advanced research infrastructure (622), sufficient research infrastructure (722) and insufficient research infrastructure (371).

\subsection{The econometric models}

We compare the categories presented in the previous sections separately, in order to generate two econometric models in which the dependent variable is a binary answer $(0 \text { or } 1)^{17}$, as presented in Table 3. Table 3 - Econometric models proposed

\begin{tabular}{c|l|c}
\hline \hline Econometric Models & \multicolumn{1}{|c|}{ Categories } & Binary answer \\
\hline \multirow{2}{*}{ Model 1 } & Insufficient research infrastructure & 0 \\
\cline { 2 - 3 } & Advanced research infrastructure & 1 \\
\hline \multirow{2}{*}{ Model 2 } & Insufficient research infrastructure & 0 \\
\cline { 2 - 3 } & Sufficient research infrastructure & 1 \\
\hline \hline
\end{tabular}

Source: Authors' own elaboration.

14 Empresa Brasileira de Pesquisa Agropecuária - Embrapa.

15 Aeronautics Institute of Technology (Instituto Tecnológico de Aeronáutica - ITA), Aeronautics and Space Institute (Instituto de Aeronáutica e Espaço - IAE) and Advanced Studies Institute (Instituto de Estudos Avançados - IEAv).

16 We are aware that the dependent variable is subjective, depending on the knowledge of each research leader about the state of the art of their scientific knowledge field. However, as our aim is to measure the relative scientific modernity of the Brazilian infrastructures, and to our concern this is the best way to proceed with our analysis considering information available in the database. Therefore, despite being a point of criticism, we follow this approach considering that research leaders' perception on research infrastructure's relative technical modernity is considered as a proxy for scientific capability. For this, we consider two axioms: firstly, no one has more information about research infrastructures than the research leaders; secondly, research leaders have complete information about their knowledge field, therefore they are able to compare their labs with all existing research labs throughout the world.

17 An ordered Probit/Logit model would be preferred by some researchers to perform the empirical analysis. However, our methodological choice lies upon the flexibility of comparison. When applying two distinct models (Probit or Logit), one can observe different values of coefficients when comparing the three groups of dependent variables (insufficient, sufficient and advanced). If ordered model (Logit or Probit) were chosen, the resulting coefficient would be just one, the result of comparison of two groups against one group (for example, insufficient and sufficient against advanced or advanced and sufficient against insufficient). 
Table 4 - Explanatory variables

\begin{tabular}{|c|c|c|}
\hline Explanatory Variables & Description & $\begin{array}{l}\text { Theoretical } \\
\text { intent }\end{array}$ \\
\hline $\begin{array}{l}\text { Monetary value } \\
\text { attributed }^{18}\end{array}$ & $\begin{array}{l}\text { It is considered four categories: } \\
\text { a) up to US\$ } 230.000 \text { (base category); } \\
\text { b) from US\$ } 231.000 \text { to US\$ } 462.000 \text {; } \\
\text { c) from US } \$ 463.000 \text { to US\$ } 4,63 \text { million; } \\
\text { d) above US\$ } 4,63 \text { million. }\end{array}$ & Economies of scale \\
\hline Multidisciplinarity & $\begin{array}{l}\text { Dummy variable: } \\
\text { a) multidisciplinary scientific infrastructures }(1) \\
\text { b) otherwise }(0)\end{array}$ & Economies of scope \\
\hline $\begin{array}{l}\text { Modernization } \\
\text { period }\end{array}$ & $\begin{array}{l}\text { Variable that indicates when the last modernization was carried out in the } \\
\text { scientific infrastructure. Categories are: } \\
\text { a) up to } 1 \text { year (base category); } \\
\text { b) from } 1 \text { to } 5 \text { years; } \\
\text { c) from } 5 \text { to } 10 \text { years; } \\
\text { d) from } 10 \text { to } 15 \text { years; } \\
\text { e) there was none. }\end{array}$ & Technological vanguard \\
\hline $\begin{array}{l}\text { Operation time } \\
\quad \text { (lifespan) }\end{array}$ & Infrastructures' operation period. & $\begin{array}{l}\text { Importance of the longevity of } \\
\text { the research } \\
\text { (proxy for research maturity) }\end{array}$ \\
\hline $\begin{array}{l}\text { Cooperation with } \\
\text { Brazilian Research } \\
\text { institutions }\end{array}$ & $\begin{array}{l}\text { Importance attributed (low, medium or high importance) for the } \\
\text { cooperation with other Brazilian research institutions. The base category is } \\
\text { 'low importance'. }\end{array}$ & Interaction with \\
\hline $\begin{array}{l}\text { Cooperation with } \\
\text { foreign research } \\
\text { institutions }\end{array}$ & $\begin{array}{l}\text { Importance attributed (low, medium or high importance) for the } \\
\text { cooperation with foreign research institutions. The base category is 'low } \\
\text { importance'. }\end{array}$ & S\&T peers \\
\hline $\begin{array}{l}\text { Cooperation with } \\
\text { domestic firms }\end{array}$ & $\begin{array}{l}\text { Importance attributed (low, medium or high importance) for the } \\
\text { cooperation with domestic firms. The base category is 'low importance'. }\end{array}$ & \\
\hline $\begin{array}{l}\text { Cooperation with } \\
\text { foreign firms }\end{array}$ & $\begin{array}{l}\text { Importance attributed (low, medium or high importance) for the } \\
\text { cooperation with foreign industrial firms. The base category is 'low } \\
\text { importance'. }\end{array}$ & University-industry interactions \\
\hline Geographic Regions & $\begin{array}{l}\text { Dummy variable for Brazilian regions (Southeast, South, Northeast, North } \\
\text { and Midwest). The base category is 'Southeast region'. }\end{array}$ & Control group \\
\hline Science Index & $\begin{array}{l}\text { Factor Analysis for the number of research articles, book chapters and } \\
\text { published books by researchers. }\end{array}$ & Scientific results' importance \\
\hline Technology Index & $\begin{array}{l}\text { Factor Analysis for the number of patent applications (national and } \\
\text { international). }\end{array}$ & $\begin{array}{l}\text { Technological results' } \\
\text { importance }\end{array}$ \\
\hline
\end{tabular}

Source: Authors' own elaboration.

The control group is the "insufficient research infrastructure" category (dummy $=0$ ). We use Logit and Probit econometric techniques to generate results for both models. We also perform Shapiro-Wilk and Shapiro-Francia Normality tests on the dependent variable. This procedure specifies that such variables follow a normal distribution, which indicates the use of a Probit model. Despite that, many researchers opt to use a Logit model since the interpretation of the coefficients is easier. In addition, by the Central Limit Theorem, the logistic distribution approaches the normal distribution. Therefore, to avoid any criticism, we opt to use both techniques. Algebraic specifications follow Wooldridge (2002). The considered explanatory variables are as specified in Table 4. We present in Table 5 and Table 6 descriptive statistics about all variables used in the econometric models.

Table 5 - Descriptive statistics - dummy variables

\begin{tabular}{|c|c|c|}
\hline Variables & Number & Percentage \\
\hline \multicolumn{3}{|l|}{ Research infrastructure } \\
\hline Advanced & 622 & $36.3 \%$ \\
\hline Sufficient & 722 & $42.1 \%$ \\
\hline Insufficient & 371 & $21.6 \%$ \\
\hline \multicolumn{3}{|l|}{ Monetary value attributed } \\
\hline up to USD 230.000 & 1,023 & $59.7 \%$ \\
\hline from USD 231.000 to USD 462.000 & 294 & $17.2 \%$ \\
\hline from USD 463.000 to USD 4,63 million & 344 & $20.1 \%$ \\
\hline
\end{tabular}

${ }^{18}$ The original values were quoted in Brazilian Reais (BRL). We convert to US Dollars (USD) considering the average exchange rate of 2013 (period when the research was conducted). 


\begin{tabular}{|c|c|c|c|}
\hline & above USD 4,63 million & 53 & $3.1 \%$ \\
\hline Multidisciplinarity & & 285 & $16.6 \%$ \\
\hline \multicolumn{4}{|c|}{ Modernization period } \\
\hline & up to 1 year & 560 & $32.7 \%$ \\
\hline & from 1 to 5 years & 673 & $39.2 \%$ \\
\hline & from 5 to 10 years & 190 & $11.1 \%$ \\
\hline & from 10 to 15 years & 106 & $6.2 \%$ \\
\hline & there was none & 186 & $10.8 \%$ \\
\hline \multicolumn{4}{|c|}{ Cooperation with domestic research institutions } \\
\hline & Low importance attribution & 444 & $25.9 \%$ \\
\hline & Medium importance attribution & 523 & $30.5 \%$ \\
\hline & High importance attribution & 748 & $43.6 \%$ \\
\hline \multicolumn{4}{|c|}{ Cooperation with foreign research institutions } \\
\hline & Low importance attribution & 964 & $56.2 \%$ \\
\hline & Medium importance attribution & 335 & $19.5 \%$ \\
\hline & High importance attribution & 416 & $24.3 \%$ \\
\hline \multicolumn{4}{|c|}{ Cooperation with domestic firms } \\
\hline & Low importance attribution & 1,055 & $61.5 \%$ \\
\hline & Medium importance attribution & 309 & $18.0 \%$ \\
\hline & High importance attribution & 351 & $20.5 \%$ \\
\hline \multicolumn{4}{|c|}{ Cooperation with foreign firms } \\
\hline & Low importance attribution & 1,589 & $92.7 \%$ \\
\hline & Medium importance attribution & 76 & $4.4 \%$ \\
\hline & High importance attribution & 50 & $2.9 \%$ \\
\hline \multicolumn{4}{|l|}{ Geographic regions } \\
\hline & Southeast & 977 & $57.0 \%$ \\
\hline & South & 411 & $24.0 \%$ \\
\hline & Northeast & 164 & $9.6 \%$ \\
\hline & North & 52 & $3.0 \%$ \\
\hline & Midwest & 111 & $6.5 \%$ \\
\hline
\end{tabular}

Source: Authors' own elaboration.

Some initial observations may be extracted from the information presented in the previous Tables. A large number of research infrastructures are classified as "advanced" or "sufficient" and have been recently modernized (up to 5 years). However, they have limited scale and limited muldisciplinary use. They are mainly located in the Southeast and South regions of the country, confirming other studies that show the regional concentration of science production in Brazil (Chiarini et al., 2013).

Furthermore, research infrastructures are more able to establish cooperation with domestic peers than with foreign ones, showing that Brazilian research infrastructures are not yet internationalized. In addition, we can notice that cooperation with (domestic or foreign) firms is not seen as of high-importance, corroborating the current literature on the topic (Silva Neto et al., 2013). The observation of S\&T indexes, presented in Table 6, corroborate the previous finding, since the average value for "science" is higher than for "technology".

Table 6 - Descriptive statistics - continuous and discrete variables

\begin{tabular}{l|c|c|c|c|c}
\hline \multicolumn{1}{c|}{ Variables } & Number & Average & S-D & Lower limit & Upper limit \\
\hline Operation time (lifespan) & 1,715 & 14.65 & 12.79 & 0 & 104 \\
Science Index & 1,715 & 0.0051 & 0.98 & -0.60 & 14.33 \\
Technology Index & 1,715 & 0.0036 & 0.80 & -0.19 & 18.56 \\
\hline
\end{tabular}

Source: Authors' own elaboration.

\section{$5 \quad$ Results and Discussions}

We present in Table 7 results from our econometric models. We opt in presenting also odds-ratio from the Logit model since it is of practical understanding. 
Table 7 - Econometric models

\begin{tabular}{|c|c|c|c|c|c|c|}
\hline \multirow{2}{*}{ Variables } & \multicolumn{3}{|c|}{$\begin{array}{c}\text { Model 1 } \\
\text { Comparison with advanced research } \\
\text { infrastructures }\end{array}$} & \multicolumn{3}{|c|}{$\begin{array}{c}\text { Model } 2 \\
\text { Comparison with sufficient research } \\
\text { infrastructures }\end{array}$} \\
\hline & Logit & $\begin{array}{l}\text { Odds- } \\
\text { Ratio } \\
\text { Logit }\end{array}$ & Probit & Logit & $\begin{array}{c}\text { Odds-Ratio } \\
\text { Logit }\end{array}$ & Probit \\
\hline $\begin{array}{l}\text { Monetary value attributed to the infrastructure } \\
\text { from USD } 231.000 \text { to USD } 462.000 \\
\text { from USD } 463.000 \text { to USD } 4,63 \text { million } \\
\text { above USD } 4,63 \text { million }\end{array}$ & $\begin{array}{l}1.27^{*} \\
2.44^{*} \\
\text { empty }\end{array}$ & $\begin{array}{l}3.56^{*} \\
11.51^{*} \\
\text { empty }\end{array}$ & $\begin{array}{c}0.72 * \\
1.38 * \\
\text { empty }\end{array}$ & $\begin{array}{c}0.67^{*} \\
1.10^{*} \\
\text { empty }\end{array}$ & $\begin{array}{c}1.95^{*} \\
3.00^{*} \\
\text { Empty }\end{array}$ & $\begin{array}{l}0.40^{*} \\
0.64^{*} \\
\text { empty }\end{array}$ \\
\hline Multidisciplinarity & $0.40 * *$ & $1.50 * *$ & $0.21 * * *$ & 0.02 & 1.02 & 0.00 \\
\hline Modernization period & $\begin{array}{l}-0.19 \\
-1.05^{*} \\
-1.90^{*} \\
-1.92 *\end{array}$ & $\begin{array}{l}0.83 \\
0.35^{*} \\
0.15^{*} \\
0.15^{*}\end{array}$ & $\begin{array}{l}-0.13 \\
-0.63 * \\
-1.11 * \\
-1.12 *\end{array}$ & $\begin{array}{l}-0.16 \\
-0.79 * \\
-1.25 * \\
-1.30 *\end{array}$ & $\begin{array}{l}0.85 \\
0.45^{*} \\
0.29 * \\
0.27^{*}\end{array}$ & $\begin{array}{l}-0.10 \\
-0.48 \\
-0.77^{*} \\
-0.80^{*}\end{array}$ \\
\hline Operation time (lifespan) & $0.02 *$ & $1.02 *$ & $0.01 * *$ & $0.02 * *$ & $1.02 * *$ & $0.01^{*}$ \\
\hline $\begin{array}{l}\text { Cooperation with domestic research institutions } \\
\text { Medium importance attribution } \\
\text { High importance attribution }\end{array}$ & $\begin{array}{l}0.69 * \\
0.80 *\end{array}$ & $\begin{array}{l}1.99^{*} \\
2.23 *\end{array}$ & $\begin{array}{l}0.40^{*} \\
0.47^{*}\end{array}$ & $\begin{array}{l}0.192 \\
0.114 \\
\end{array}$ & $\begin{array}{l}1.211 \\
1.121 \\
\end{array}$ & $\begin{array}{l}0.118 \\
0.075 \\
\end{array}$ \\
\hline $\begin{array}{l}\text { Cooperation with foreign research institutions } \\
\text { Medium importance attribution } \\
\text { High importance attribution }\end{array}$ & $\begin{array}{l}0.84^{*} \\
1.35^{*} \\
\end{array}$ & $\begin{array}{l}2.31^{*} \\
3.85^{*}\end{array}$ & $\begin{array}{l}0.49^{*} \\
0.76^{*}\end{array}$ & $\begin{array}{c}0.285 \\
-0.227 \\
\end{array}$ & $\begin{array}{l}1.330 \\
0.796 \\
\end{array}$ & $\begin{array}{r}0.167 \\
-0.135 \\
\end{array}$ \\
\hline $\begin{array}{r}\text { Cooperation with domestic firms } \\
\text { Medium importance attribution } \\
\text { High importance attribution }\end{array}$ & $\begin{array}{l}0.59^{*} \\
0.87^{*}\end{array}$ & $\begin{array}{l}1.81 * \\
2.39 *\end{array}$ & $\begin{array}{c}0.33 * * \\
0.49 *\end{array}$ & $\begin{array}{l}0.35 * * * \\
0.40 * * *\end{array}$ & $\begin{array}{l}1.41 * * * \\
1.48 * * *\end{array}$ & $\begin{array}{l}0.21 * * * \\
0.23 * * *\end{array}$ \\
\hline $\begin{array}{l}\text { Cooperation with foreign firms } \\
\qquad \begin{array}{r}\text { Medium importance attribution } \\
\text { High importance attribution }\end{array}\end{array}$ & $\begin{array}{l}0.43 \\
0.11 \\
\end{array}$ & $\begin{array}{l}1.63 \\
1.12 \\
\end{array}$ & $\begin{array}{l}0.20 \\
0.08\end{array}$ & $\begin{array}{c}0.25 \\
-0.32 \\
\end{array}$ & $\begin{array}{l}1.28 \\
0.73\end{array}$ & $\begin{array}{c}0.12 \\
-0.17 \\
\end{array}$ \\
\hline $\begin{array}{r}\text { South } \\
\text { Northeast } \\
\text { North } \\
\text { Midwest } \\
\end{array}$ & $\begin{array}{l}-1.16^{*} \\
-0.82^{*} \\
-1.66^{*} \\
-1.65^{*} \\
\end{array}$ & $\begin{array}{l}0.31^{*} \\
0.44^{*} \\
0.19^{*} \\
0.19^{*} \\
\end{array}$ & $\begin{array}{l}-0.67 * \\
-0.46 * \\
-1.00^{*} \\
-0.93 \\
\end{array}$ & $\begin{array}{l}-0.49 * \\
-0.05 \\
-0.19 \\
-0.25 \\
\end{array}$ & $\begin{array}{c}0.61 * \\
0.945 \\
0.83 \\
0.78 \\
\end{array}$ & $\begin{array}{l}-0.29 * \\
-0.01 \\
-0.12 \\
-0.14 \\
\end{array}$ \\
\hline $\begin{array}{l}\text { Science Index } \\
\text { Technology Index } \\
\text { Constant }\end{array}$ & $\begin{array}{l}0.17 \\
-0.06 \\
-0.75^{*} \\
\end{array}$ & $\begin{array}{r}1.18 \\
0.95 \\
0.47^{*} \\
\end{array}$ & $\begin{array}{l}0.10 \\
-0.03 \\
-0.43^{*} \\
\end{array}$ & $\begin{array}{c}0.21 \\
-0.18 \\
0.71 * \\
\end{array}$ & $\begin{array}{c}1.23 \\
0.84 \\
2.03 * \\
\end{array}$ & $\begin{array}{c}0.12 \\
-0.10 \\
0.43 * \\
\end{array}$ \\
\hline Observations & \multicolumn{3}{|c|}{1715} & \multicolumn{3}{|c|}{1715} \\
\hline $\begin{array}{l}\text { LR (qui-square) } \\
\text { Prob > qui-square } \\
\text { Pseudo-R }{ }^{2}\end{array}$ & \multicolumn{2}{|c|}{$\begin{array}{c}491.17 \\
0.00 \\
0.387\end{array}$} & $\begin{array}{c}490.55 \\
0.00 \\
0.386\end{array}$ & \multicolumn{2}{|c|}{$\begin{array}{c}140.24 \\
0.00 \\
0.101\end{array}$} & $\begin{array}{c}140.94 \\
0.00 \\
0.101\end{array}$ \\
\hline
\end{tabular}

Source: Authors' own elaboration. Notes: $(*, * *, * *)$ : significant at $1 \%, 5 \%$ and $10 \%$ respectively. Control Groups: 'insufficient research infrastructure'; monetary value attributed: 'up to US\$ 230.000'; modernization period: 'up to 1 year'; geographic regions: 'southeast'; cooperation: 'low importance'.

Models are adjusted rapidly by the likelihood method (five interactions), and chi-square value presents statistical significance for both regressions. Still, results achieved by both Logit and Probit methods were congruent (both for significance and coefficients' signs).

\subsection{Economies of scale and scope}

Economies of scale and scope are documented in the literature as important features of industrial capitalism (Chandler, 1994), being the cost-diminishing by increase of production (scale) or by producing goods with complementary productive process (scope). Alternatively, one may highlight the inverse of cost (productivity) as the focus of analysis from scale and scope economies; in this view, a firm may produce more increasing its factory size as well as increasing the number of complementarity products produced at same factory.

As presented in the theoretical framework, some studies consider these features in measuring scale and scope at research for distinct variables and levels, and public policies have been created to strengthen research infrastructures and incentivize their growth (EC, 2010; OECD, 2010). 
We try to capture the importance of economies of scale for research infrastructures in Brazil. The results we find are slightly different from those already presented in the literature once we do not measure outputs but the relative perception of research leaders when comparing their research infrastructures with others domestically and internationally. In doing so, they consider the relative quality in producing scientific results for a given infrastructure.

Having that in mind, our econometric estimations point out to the importance of scale for research infrastructures in Brazil. First of all, we found there is no singular research infrastructure whose monetary value is above USD 4,63 million classified as "insufficient"; they are either classified as "advanced" $(82 \%$ of time) or "sufficient" (18\% of time).

Research infrastructures whose monetary value attributed is above USD 463 thousand are 11.5 times more likely to be classified as 'advanced' than infrastructures bellow USD 231 thousand. According to research leader's perception, the relevance of scale is monotone-increasing. When analyzing the sufficient research infrastructures (Model 2, Table 7), coefficients' signals are the same as Model 1, however with smaller magnitudes. Scale is closely related to quality perception, so the question about the catching up of research infrastructures pass on an improvement on machinery, equipment and physical installations.

In what regards the scope of research infrastructures, the results follow pretty much the same pattern as their scale, however in smaller magnitude and only for advanced research infrastructures. Multidisciplinary research infrastructures have $49,8 \%$ more chances to be classified as "advanced" in comparison with "insufficient" ones. The same is not valid for "sufficient" versus "insufficient" comparisons, as can be seen by the presence of coefficients econometrically insignificant.

When putting in parallel research infrastructures' scale and scope, one can note a greater importance to the first. As a consequence, increments on research infrastructure's scale are an important improvement observed by research leaders. Therefore, as almost $60 \%$ of research infrastructures are monetarily worth less than USD 230 thousand, an improvement on monetary values for scientific breakthrough is raised. Besides, U-shaped relation would not be identified from our database since the percentage of advanced research infrastructure is monotonically increasing for their attributed monetary value $(42.1 \%, 77.8 \%$, $92.5 \%$ and $100 \%$ respectively). That means that research infrastructures seem to be in the crescent side of the curve.

\subsection{Technological progress and research maturity}

Scientific developments are frequently supported and increased by technological improvements (Kline; Rosenberg, 1986). Nowadays, with the rapid advancements of science and the fast-technological obsolescence, the importance of research infrastructure modernization is even more urgent. This is wellcaptured by our econometric models. Coefficients are significant for both models (from five years of modernization on), even with greater magnitude for "advanced versus insufficient" research infrastructure comparison. Two observations are interesting and may be considered for both models regarding technological obsolescence.

First of all, research infrastructures modernized more than ten years before the Survey are classified as bad as infrastructure with no modernization, since coefficients are statistically the same. In a few words, those research infrastructures are roughly 6.8 times less likely to be "advanced" and roughly 3.8 times less likely to be "sufficient", as one can expect. Secondly, the Survey respondents consider there is no difference between "up to 1 year" and "from 1 to 5 years" classifications, which indicate a "satisfaction" degree until the upper limit (five years). After that, research infrastructure seems to be impaired.

The previous findings bring out relevant insights for those who subsidize research institutions: constant modifications have to be made in their labs, at least in the medium term, so research infrastructures can sustain their quality standards. Since the majority of scientific infrastructures are maintained by federal government in Brazil (De Negri; Squeff, 2016), the problem is even more pressing with economic authority and the constant budget reductions in the last years (Carvalho, 2018), especially for S\&T.

Additionally, we tested our model for the influence of research maturity, which can be explained by the research infrastructure lifespan. The variable is also able to identify a learning curve (Ritter; Schooler, 2002). Despite statistical significance, the impact of the operation lifespan is very small in both models, 
which leads us to suggest that opportunities can be achieved by new labs. This result is in line with the one found by Cohen (1991), who proposes that there is no indication of timing entry barriers.

\subsection{Cooperation}

Cooperation and interactions are relevant for a NSI (Freeman, 1992), as already presented previously. Some studies highlight the importance of universities in generating technologies, both inside and outside their boundaries (Cohen et al., 2002; Wright, Birley \& Mosey, 2004). Besides that, specific attention is given to university-firm interactions (Sjoo \& Hellstrom, 2019; Klevorick et al., 1995; Mansfield, 1991), and the Brazilian case is not an exception (Caliari \& Rapini, 2017; Caliari, Santos, \& Mendes, 2016; Rapini, 2007; Suzigan \& Albuquerque, 2011).

In this paper, we tested the cooperation of research infrastructure with other labs and their interactions with firms, both classified as domestic and foreign. Results show different perspectives from research leaders in accessing "advanced" or "sufficient" classifications. For research infrastructure classified as "sufficient", cooperation with domestic firms presents statistical significance while with foreign firms it does not. It is worth noting as well that there is no difference among medium and high levels of importance of cooperation with domestic firms. Furthermore, the coefficient of cooperation is smaller than the coefficients of other explanatory variables.

We also find evidences that structural changes on research infrastructure may be achieved with cooperation. For example, a research lab which gave high importance to interactions with other labs - either domestic or foreign - and to domestic firms are approximately 8.5 times more likely to be "advanced" than research infrastructure which gave low importance to these interactions.

Cooperation with foreign firms was not markedly important to differentiate infrastructure technical capacity. The high importance given to cooperate with foreign firms is underscored by only 31 advanced scientific labs $(4,9 \%)$ while other types of cooperation were indicated as important by $57.9 \%$ (domestic institutions), $33.8 \%$ (foreign institutions) and 32.3\% (domestic firms) of those scientific infrastructures.

\subsection{Geographic regions}

Regions are important for knowledge creation and learning, therefore regions' research structure may generate feedbacks on the regions' economic system (Florida, 1995). This process is related to Myrdal's circular cumulative causation (Myrdal, 1960) where inequalities are reinforced by the system; in this view, strong economies are associated with strong regional innovation systems in a self-reinforcement process (Cooke, 2001; Santos \& Caliari, 2012).

Taking this into account, a correlation among economy size and research structure is expected, which means relatively more advanced research infrastructure are located in more advanced economic regions. Table 8 presents information to sustain these arguments, repeating econometric results (column 2) besides economic and S\&T regional concentrations (columns 3 and 4). Econometric coefficients are from odds-ratio results; all of them are statistically significant.

Table 8 - Comparative Information under Regional Classification

\begin{tabular}{|c|c|c|c|}
\hline Geographic Region & $\begin{array}{c}\text { Probability of being } \\
\text { advanced }\end{array}$ & $\begin{array}{l}\% \text { of research } \\
\text { infrastructures }\end{array}$ & $\begin{array}{c}\% \text { of Brazilian } \\
\text { GDP }\end{array}$ \\
\hline Southeast & 1.00 & 57.0 & 54.0 \\
\hline South & 0.31 & 24.0 & 16.8 \\
\hline Northeast & 0.44 & 9.6 & 14.2 \\
\hline North & 0.19 & 3.0 & 5.3 \\
\hline Midwest & 0.19 & 6.5 & 9.7 \\
\hline
\end{tabular}

Source: Authors' own elaboration.

As it can be seen in Table 8, the percentage of research structures are correlated with the size of each regions' economies (GDP), however we can notice that the former is more concentrated than the latter (Hirschman-Herfindahl index for research infrastructure is 3,968.4, while for GDP is 3,522.1). This means 
a high degree of reinforcement of S\&T effects on the economic structure, which is congruent with Cavalcante (2011). We can also find in the literature econometric evidences that prove that the uneven distribution of S\&T resources in the country is mainly explained by the imbalanced regional research infrastructure (Fagundes et al, 2005). Moreover, other studies show that the research infrastructure asymmetry within regions reflect their S\&T outputs (Chiarini et al., 2013; Sidone et al, 2016).

Our finding goes against the policy implemented by federal governments in the 2000s and middle 2010s for the decentralization of higher education (BRASIL, 2015; Pires \& Silva, 2009). Our analysis show that despite the implementation of policies to decentralize the research infrastructure with the inauguration of new research institutes in the Northeast - such as the Center for Strategic of the Northeast ${ }^{19}$ and the Semi Arid National Institute ${ }^{20}$ - and the establishment of new public universities in the Northeast and Midwest - such as the Federal University of Recôncavo da Bahia - UFRB, and the Federal University of Grande Dourados - UFGD -, research infrastructures are still highly concentrated. Those policies had positive immigration effects of students for less-developed regions (Barufi, 2014), however, relevant research infrastructures are still more concentrated than the provision of higher education. Then, circular cumulative causation effects are established, which the decrease in retention of students in those less-developed areas.

This inequality reinforcement feedback can be seen in the econometric analysis: research infrastructures located in the Southeast Region are approximately 5.2 times more likely to be "advanced" than research infrastructures in the North and Midwest Regions, for example. Northeast Region seems to be an outlier. Despite its low percentage of research infrastructure $(9.6 \%$ of total research infrastructure from Brazil is located there), $44 \%$ of them seem to be comparable with the ones from the Southeast Region, which is a higher number even compared to the South Region (31\%). Here there may be a virtuous result from regional policies, since economic growth in the Northeast was higher than Brazil's average in the last years, but more studies need to be done to deepen this finding.

\subsection{Scientific and Technological Outputs}

Scientific and technological results (publications and patents) are possible outputs from research infrastructures. Additionally, one can remind that there are intangible benefits, spillovers and externalities of the investment in research infrastructure (Del Bo et al., 2016) that was not captured in our models

Our findings reveal that neither scientific nor technological results are statistically significant on research leader's perception on their research infrastructure. Notwithstanding this result, we believe it may be related with existing correlations among both labs' economic scale and scientific/technological results, as we can depict from Table 9.

Table 9 - Comparative Information about scientific and technological outputs

\begin{tabular}{l|c|c}
\hline \multicolumn{1}{c|}{ Monetary value attributed } & Average Scientific Output & $\begin{array}{c}\text { Average Technological } \\
\text { Output }\end{array}$ \\
\hline Up to USD 231.000 & -0.130 & -0.076 \\
From USD 232.000 to US\$ 463.000 & 0.158 & -0.006 \\
From USD 463.000 to US\$ 4,63 million & 0.228 & 0.199 \\
Above USD 4,63 million & 0.334 & 0.118 \\
\hline \hline
\end{tabular}

Source: Authors' own elaboration.

There is a monotonically and mathematically crescent relationship between the research infrastructure scale and average scientific outputs, however the same conclusion is not valid for scale and technological output. As a consequence, we made particular tests to verify the former association. We do not find multicollinearity when testing the dependent variables by VIF command ${ }^{21}$, but it is not a definite conclusion since research infrastructure scale is defined by a Likert scale type. Consequently, we processed

19 Centro de Tecnologias Estratégicas do Nordeste-CETENE.

20 Instituto Nacional do Semiárido - INSA.

21 Results for multicollinearity test are presented in Table 10 (annex). 
alternative regressions without infrastructure scale and considering only for the Logit model (Table 10, annex).

When using these alternative regressions, we identify two relevant findings: i) scientific outputs are statistically significant to explain both 'advanced' and 'sufficient' research infrastructure, as suggested before; and ii) all remaining explanatory variables present the same results (considering sign, magnitude and statistical significance of coefficients), which indicate the validity of scale and science' correlations, with robust results for further variables. Better statistical adjustments came from main models so we are already considering the best econometric fit.

\section{Conclusions}

In Brazil, research infrastructures started to be built about 50 to 60 years ago. Today, the country has a considerable developed research infrastructure constituted, in the majority, by public labs within public universities and public research institutes. So, this structure is due mainly by efforts from federal government in last decades.

Considering that and the importance of infrastructure for S\&T advancements, an extensive work was conducted in order to quantify S\&T infrastructures (De Negri \& Squeff, 2016). We used this database and we identified the determinants of the relevance of research infrastructure, categorized as "advanced", "sufficient" or "insufficient". Our econometric results corroborate theoretical and empirical findings, with distinct impact from variables, allowing to define hierarchy.

Firstly, being bigger (infrastructure scale) and having state-of-art technology are remarkably important to reach "advanced" status. Considering the previous finding, increasing labs' scale seems to be a more urgent need than their modernization: roughly $72 \%$ of scientific infrastructures were modernized in the last 5 years, but only $23 \%$ of them are monetarily valued above US\$ 463 thousand. However, relatively modern infrastructure does not maintain its modernity if no further investments is done.

We also found evidences that interactions with other agents of the Brazilian Innovation System have impacts on the research infrastructure. Researchers who perceive as "high important" the interactions with other labs - both domestic and foreign ones - and also with Brazilian firms are approximately 8.5 times more likely to be relatively more "advanced" than those researchers who consider these interactions of "low importance". Despite that, the interactions are focused mainly in peer-cooperation (research institutions) and domestic firms, which corroborates the low cooperation profile of Brazilian institutions. On this way, many discussions regarding current improvements for Brazilian S\&T capabilities focus on the need of establish more cooperative arrangements, mainly with foreign institutions and firms.

Scope, scientific output and operation lifespan also present statistical significance, but with lower magnitude. Additionally, results present inequality reinforcement feedback from regional analysis, which need to be tackled if policy makers are trying to sought a strategy focused on scientific regional inequality reduction.

As an important appointment from this study, we highlight the susceptibility of Brazilian infrastructure to public budgetary fluctuations. Therefore, our findings are likely to be relevant for research infrastructures' managers who depend mainly on public resources, which have been reduced drastically in the last few years in Brazil. It is urgent the search for new sources of income. One possible way to overcome this reduction, in order to prevent activities interruption, is by approximating the public labs to private companies and/or foreign institutions. An efficient approximation strategy must pursue the increase scale besides sustaining modernity standards of the labs.

Our models suggest that centers of excellence tend to reach better this suggestion, since they are more attractive for private intentions. Moreover, the importance of cooperation points out the dual relevance of this strategy.

Nonetheless, it has to stay clear that private funding is mainly focused on applied technological matters, so this suggestion would be applicable just in specific fields and for specific cases. Thus, even if a cooperative approach with private institutions is achieved by some research infrastructures, it is true that some researches that do not present clear market potential should continue to depend on public entities for 
their continuity and growth. We understand, therefore, that policy makers should think in stable public policies on this matter whose importance for both economic and social developments are undeniable.

\section{References}

ACHARYA, T. Science and technology for wealth and health in developing countries. Global Public Health, v. 2, n. 1, p. 53-63, 2007.

ALBUQUERQUE, E.; SIMOES, R.; BAESSA, A.; CAMPOLINA, B.; SILVA, L.. A distribuição da produção científica e tecnológica brasileira: uma descrição de estatística de produção local de patentes e artigos científicos. Revista Brasileira de Inovação, v. 1, 2002, p. 225-51.

BARUFI, A. M. B. Impactos do Acesso ao Ensino Superior sobre a Migração de Estudantes Universitários. In: RESENDE, G. M. (Org.). . Avaliação de Políticas Públicas no Brasil uma análise de seus impactos regionais. 1. ed. Brasília: IPEA, 2014. v. 1. p. 307-352.

BERNARDES, A.T.; ALBUQUERQUE, E.M. Cross-over, thresholds, and interactions between science and technology: lessons for less-developed countries. Research Policy, v. 32, p. 865-885, 2003.

BRASIL. MINISTÉRIO DA EDUCAÇÃO. A democratização e expansão da educação superior no Brasil: 2003-2014. $\quad$ [S.1: $\quad$ s.n.], $2015 . \quad$ Disponível em: $<$ http://portal.mec.gov.br/index.php?option=com_docman\&view=download\&alias=16762-balancosocial-sesu-2003-2014\&Itemid=30192>.

BROOKS, H. The relationship between science and technology. Research Policy, v.23, p.477-486, 1994.

CALIARI, T.; RAPINI, M. S. Geographical distance differentials in university-firm interaction in Brazil: A focus on the characteristics of agents and interactions. Nova Economia, v. 27, n. 1, 2017.

CALIARI, T.; SANTOS, U. P. DOS; MENDES, P. S. Geração de Tecnologia em Universidades / Institutos de Pesquisa e a Importância da Interação com Empresas: Constatações através da Base de Dados dos Grupos de Pesquisa do CNPq. Análise Econômica, v. 34, n. 66, p. 285-312, 2016.

CASSIOLATO, J. E., SOARES. M. C. C. Innovation Systems, Development and Health. In: CASSIOLATO, J. E; SOARES, M. C. Health Innovation Systems, Equity and Development, 2015

CARVALHO, L. A valsa brasileira. São Paulo, São Paulo: Todavia Livros, 2018.

CAVAlCANTE, L. R. Desigualdades Regionais em Ciência, Tecnologia e Inovação no Brasil: Uma Análise de sua Evolução Recente. , Texto para Discussão., nº 1574. Brasília: [s.n.], 2011. Disponível em: $<\mathrm{http}: / /$ repositorio.ipea.gov.br/bitstream/11058/1470/1/TD_1574.pdf $>$. Acesso em: 28 mar. 2018.

CHANDLER, A. Scale and Scope: the Dynamic of Industrial Capitalism. Cambridge, MA: The Belknapp Press of the Harvard University Press, 1994.

CHIARINI, T.; OLIVEIRA, V. P.; DO COUTO E SILVA NETO, F. C. Spatial distribution of scientific activities: An exploratory analysis of Brazil, 2000-10. Science \& Public Policy, v. 41, pp. 625-640, 2013.

COCKBURN, I. M.; HENDERSON, R. M. Scale and scope in drug development: unpacking the advantages of size in pharmaceutical research. Journal of Health Economics, v. 20, p. 1033-1057, 2001.

COHEN, J. E. Publication rate as a function of laboratory size in a biomedical research institution. Scientometrics, v. 2, n. 1, p. 35-52, 1980.

COHEN, J. E. Size, age and productivity of scientific and technical research groups. Scientometrics, v. 20, n. 3, p. 395-416, 1991.

COHEN, W. M. et al. Links and Impacts: The Influence of Public Research on Industrial R\&D. Management Science, v. 48, n. 1, p. 1-23, 2002.

COOKE, P. Regional Innovation Systems, Clusters, and the Knowledge Economy. Industrial and Corporate Change, v. 10, n. 4, p. 945-974, 2001. 
CROW, M.; BOZEMAN, B. Limited by design: R\&D Laboratories in the US National Innovation System. New York: Columbia University Press, 1998.

DEL BO, C. F., FLORIO, M., \& FORTE, S. (2016). The social impact of research infrastructures at the frontier of science and technology: The case of particle accelerators. Technological Forecasting and Social Change, 112, 1-3.

DE NEGRI, F.; CAVALCANTE, L. R.; ALVES, P. F.. Relações universidade-empresa no Brasil: o papel da infraestrutura pública de pesquisa. Discussing Paper, n. 1901. Brasília: IPEA, 2013.

DE NEGRI, F.; SQUEFF, F. DE H. S. Sistemas setoriais de inovação e infraestrutura de pesquisa no Brasil. 1. ed. Brasília: IPEA, 2016.

D'IPPOLITO; RÜLLING, C-C.. Research collaboration in large scale research infrastructures: collaboration types and policy implications. Research Policy, 2019.

EC. European Commission. A vision for strengthening world-class research infrastructures in the ERA. Report of the expert group on research infrastructures. Brussels: European Commission, 2010.

FAGUNDES, M. E. M.; CAVALCANTE, L. R. M. T.; RAMACCIOTTI, R. E. L. Distribuição regional dos fluxos de recursos federais para ciência e tecnologia. Parcerias Estratégicas, v. 10, n. 21, p. 59-78, 2005. Disponível em: < http://seer.cgee.org.br/index.php/parcerias_estrategicas/article/viewFile/267/261>. Acesso em: 2 abr. 2019.

FLORIDA, R. Toward the Learning Region. Futures, v. 27, n. 5, p. 527-536, 1995.

FORAY, D. The economic of knowledge, MIT Press, 2004.

FORAY, D. Knowledge Policy for Development. In: KRAEMER-MBULA, E.; WAMAE, W. (Org.). . Innovation and the Development Agenda. Ottawa: OECD Publishing, 2010. p. 91-109.

FREEMAN, C. Economics of Innovation. London: Routledge, 1992.

FREEMAN, C. Technological infrastructure and international competitiveness. Industrial \& Corporate Change, v. 13, n. 3, p.541-569, 2004.

GUIMARÃES, R. Pesquisa no Brasil: a reforma tardia. São Paulo em Perspectiva, v.16, n. 4, p. 41-72, 2002.

HERNANDEZ-VILLAFUERTE, K. et al. Economies of scale and scope in publicly funded biomedical and health research: evidence from the literature. Health Research Policy and Systems, v. 15, n. 3, p. 1-17, 2017. Disponível em: <https://health-policy-systems.biomedcentral.com/track/pdf/10.1186/s12961-0160167-3? site=health-policy-systems.biomedcentral.com>. Acesso em: 20 mar. 2018.

JOHNES, J.; JOHNES, G. Costs, Eficciency and Economies of Scale and Scope in the English Higher Education Sector. $\quad$ [S.l: $\quad$ s.n.], $2016 . \quad$ Disponível em: $<$ http://eprints.lancs.ac.uk/80574/2/Johnes_and_Johnes_OxREP.pdf $>$. Acesso em: 21 mar. 2018.

KANNEBLEY, S.; BORGES, R. DE L. A.; DE PRINCE, D. Scientific production and its collective determinants: An econometric analysis for the Brazilian research labs. Science and Public Policy, v. 45, n. 5, p. 661-672, 2018.

KIM, L. Imitation to innovation: the dynamics of Korea's technological learning. Harvard Business School Press, 1997.

KLEVORICK, A. K. et al. On the sources and significance of interindustry differences in technological opportunities. Research Policy, v. 24, p. 185-205, 1995.

KLINE, S. J.; ROSENBERG, N. An Overview of Innovation. European Journal of Innovation Management, v. 38, p. 275-305, 1986.

KOSHAL, R. K.; KOSHAL, M. Economies of scale and scope in higher education: a case of comprehensive universities. Economics of Education Review, v. 18, p. 269-277, 1999. Disponível em: 
$<$ https://pdfs.semanticscholar.org/de80/7630af5c8bbc34bfcbbd67f3f6c93b7ab0f5.pdf $>$. Acesso em: 21 mar. 2018.

LEE, K. The art of economic catch-up. Barriers, detours and leapfrogging in Innovation Systems. New York: Cambridge University Press, 2019.

LOZANO, S.; RODRÍGUEZ, X-P.; ARENAS, A.. Atapuerca: evolution of scientific collaboration in an emergent large-scale research infrastructure. Scientometrics, 2014.

LUNDVALL, B-A. National Systems of Innovation. Towards a Theory of Innovation and Interactive Learning. London: Pinter Publisher, 1992.

LUNDVALL, B-A., JOSEPH, K.J., CHAMINADE, C., AND VANG, J., eds, Handbook of Innovation Systems and Developing Countries: Building Domestic Capabilities in a Global Setting, Edward Elgar, Cheltenham, 2009.

MACULAN, A. M.; MELLO, J. M. C. University start-ups for breaking lock-ins of the Brazilian economy. Science and Public Policy, v. 36, n. 2, 2009.

MANSFIELD, E. Academic research and industrial innovation. Research Policy, v. 20, p. 1-12, 1991. Disponível em: <http://www.edegan.com/pdfs/Mansfield (1991) - Academic Research and Industrial Innovation.pdf $>$. Acesso em: 26 maio 2017.

MAZZOLENI, R.; NELSON, R. The roles of research at universities and public labs in economic catch up. Laboratory of Economics and Management Sant'Anna School of Advanced Studies.Pisa, 2005.

MYRDAL, G. Teoria econômica e regiões subdesenvolvidas. (Edição Or ed. Belo Horizonte: Editora UFMG, 1960.

NELSON, R. National innovation systems: a comparative analysis. New York: Oxford University Press, 1993.

OECD. Establishing large international research infrastructures: Issues and options. Report of the Global Science Forum, 2010.

OLIVARES, M.; WETZEL, H. Competing in the higher education market: Empirical evidence for economies of scale and scope in German higher education institutions. , University of Lüneburg Working Paper Series in Economics., $n^{\circ}$ 223. Lüneburg: [s.n.], 2011.

PAVITT, K. (1991) What makes basic research economically useful. Research Police, v.20, pp. 109-119.

PEREZ, C.; SOETE, L. "Catching up in technology: entry barriers and windows of opportunity". In G.DOSI ET AL. eds. Technical Change and Economic Theory, London: Francis Pinter, pp. 458-479, 1988.

PIRES, A. C.; SILVA, M. C. P. Políticas de Regionalização da Capes: Limites e Potencialidades para a história da educação superior no Norte e Nordeste do Brasil. 2009, Uberlândia: [s.n.], 2009.

QIAO, L., MU, R., \& CHEN, K. Scientific effects of large research infrastructures in China. Technological Forecasting and Social Change, 112, 102-112, 2016.

QURASHI, M. M. Publication Rate as a function of the Laboratory / Group Size. Scientometrics, v. 6, n. 1, p. 19-26, 1984.

RAPINI, M. S. Interação Universidade-Empresa no Brasil: Evidências do Diretório dos Grupos de Pesquisa do CNPq. Estudos Econômicos, v. 37, n. 1, p. 211-233, 2007. Disponível em: $<$ http://www.scielo.br/pdf/ee/v37n1/08.pdf >. Acesso em: 26 maio 2017.

RIBEIRO, L. C.; RUIZ, R. M.; BERNARDES, A. T.; ALBUQUERQUE, E. M.. Modeling economic growth fuelled by science and technology. Estudos Econômicos, v. 40, n. 2, p. 319-340, 2010.

RITTER, F. E.; SCHOOLER, L. J. The learning curve. International Encyclopedia of the Social and Behavioral Sciences. Amsterdam: Pergamon, 2002. p. 8602-8605. 
ROSENBERG, N. Perspectives on technology. Cambridge: Cambridge University Press, 1976.

SANTOS, U. P.; CALIARI, T. Distribuição Espacial das Estruturas de Apoio às Atividades Tecnológicas no Brasil: Uma Análise Multivariada para as Cinquenta Maiores Microrregiões do País. Revista Economia (ANPEC), v. 13, n. 3b, p. 759-783, 2012.

SALTER, A.; MARTIN, B. (2001) The economic benefits of publicly funded basic research: a critical review. Research Policy, v.30, p.509-532.

SCHWARTZMAN, S. A space for science. The development of the scientific community in Brazil. Pennsylvania: The Pennsylvania State University Press, 1991.

SIDONE, O. J. G.; HADDAD, E. A.; MENA-CHALCO, J. P. A ciência nas regiões brasileiras: evolução da produção e das redes de colaboração. Transinformação, v. 28, n. 1, p. 15-31, 2016. Disponível em: $<$ http://dx.doi.org/10.1590/2318-08892016002800002>. Acesso em: 2 abr. 2019.

SILVA NETO, F. C. DO C. et al. Patterns of interaction between national and multinational corporations and Brazilian universities/public research institutes. Science and Public Policy, v. 40, p. 281-292, 2013. Disponível em: <https://academic.oup.com/spp/article-abstract/40/3/281/1630152>. Acesso em: 2 abr. 2019.

SJOO, K.; HELLSTROM, T.. University-industry collaboration: a literature review and synthesis. Industry \& Higher Education, 2019.

SUZIGAN, W.; ALBUQUERQUE, E. The underestimated role of universities for the Brazilian system of innovation. Revista de Economia Política, v. 31, n. 401666, p. 3-30, 2011.

VONORTAS, N. et al. Economies of scale and scope at the research project level. . Luxembourg: [s.n.], 2011. Disponível em: <http://publications.europa.eu/resource/cellar/fdb9ae6b-9fa6-4151-94d17057e4d32197.0001.02/DOC_1>. Acesso em: 20 mar. 2018.

VONORTAS, N. S. Scale and scope in research. In: DELANGHE, H.; MULDUR, U.; SOETE, L. (Org.). . European Science and Technology Policy: Towards Integration or Fragmentation? [S.1.]: Edward Elgar, 2009. p. $142-158$.

WOOLDRIDGE, J. M. Econometric Analysis of Cross Section and Panel Data. Cambridge: MIT Press, 2002.

WRIGHT, M.; BIRLEY, S.; MOSEY, S. Entrepreneurship and University Technology Transfer. Journal of Technology Transfer, v. 29, p. 235-246, 2004. 


\section{Annex}

Table 10 - Multicollinearity test for dependent variables

\begin{tabular}{|c|c|c|}
\hline Variables & VIF & $1 / \mathrm{VIF}$ \\
\hline $\begin{array}{l}\text { Monetary value attributed to the infrastructure } \\
\text { from USD } 231.000 \text { to USD } 462.000 \\
\text { from USD } 463.000 \text { to USD } 4,63 \text { million } \\
\text { above USD } 4,63 \text { million }\end{array}$ & $\begin{array}{l}1.37 \\
1.68 \\
1.89 \\
\end{array}$ & $\begin{array}{l}0.731 \\
0.596 \\
0.529 \\
\end{array}$ \\
\hline Multidisciplinarity & 1.30 & 0.768 \\
\hline $\begin{array}{r}\text { from } 1 \text { to } 5 \text { years } \\
\text { from } 5 \text { to } 10 \text { years } \\
\text { from } 10 \text { to } 15 \text { years } \\
\text { there was none }\end{array}$ & $\begin{array}{l}1.89 \\
1.31 \\
1.23 \\
1.27\end{array}$ & $\begin{array}{l}0.529 \\
0.764 \\
0.812 \\
0.789\end{array}$ \\
\hline Operating time (lifespan) & 2.76 & 0.362 \\
\hline $\begin{array}{r}\text { Cooperation with domesticresearch institutions } \\
\text { Medium importance attribution } \\
\text { High importance attribution }\end{array}$ & $\begin{array}{l}2.10 \\
3.65\end{array}$ & $\begin{array}{l}0.475 \\
0.274\end{array}$ \\
\hline $\begin{array}{r}\text { Cooperation with foreign research institutions } \\
\text { Medium importance attribution } \\
\text { High importance attribution }\end{array}$ & $\begin{array}{l}1.66 \\
2.34\end{array}$ & $\begin{array}{l}0.602 \\
0.428\end{array}$ \\
\hline $\begin{array}{l}\text { Medium importance attribution } \\
\text { High importance attribution }\end{array}$ & $\begin{array}{l}1.38 \\
1.77\end{array}$ & $\begin{array}{l}0.723 \\
0.565\end{array}$ \\
\hline $\begin{array}{r}\text { Medium importance attribution } \\
\text { High importance attribution } \\
\end{array}$ & $\begin{array}{l}1.23 \\
1.20 \\
\end{array}$ & $\begin{array}{l}0.813 \\
0.832 \\
\end{array}$ \\
\hline $\begin{array}{r}\text { South } \\
\text { Northeast } \\
\text { North } \\
\text { Midwest }\end{array}$ & $\begin{array}{l}1.30 \\
1.11 \\
1.04 \\
1.10\end{array}$ & $\begin{array}{l}0.767 \\
0.898 \\
0.960 \\
0.907\end{array}$ \\
\hline $\begin{array}{l}\text { Science Index } \\
\text { Technology Index }\end{array}$ & $\begin{array}{l}1.13 \\
1.08 \\
\end{array}$ & $\begin{array}{l}0.888 \\
0.930 \\
\end{array}$ \\
\hline
\end{tabular}

Source: Authors' own elaboration. 
Table 11 - Alternative Econometric Model

\begin{tabular}{|c|c|c|}
\hline Variables & $\begin{array}{c}\text { Model } 1 \\
\text { Odds-Ratio Logit }\end{array}$ & $\begin{array}{c}\text { Model } 2 \\
\text { Odds-Ratio Logit }\end{array}$ \\
\hline Multidisciplinarity & $1.590 * *$ & 1.095 \\
\hline \multicolumn{3}{|l|}{ Modernization period } \\
\hline from 1 to 5 years & 0.787 & 0.830 \\
\hline from 5 to 10 years & $0267 *$ & $0.434 *$ \\
\hline from 10 to 15 years & $0.151 *$ & $0.285 *$ \\
\hline there was none & $0.138 *$ & $0.254 *$ \\
\hline Operation time (lifespan) & $1.031 *$ & $1.021 *$ \\
\hline \multicolumn{3}{|l|}{ Cooperation with domestic research institutions } \\
\hline Medium importance attribution & $1.759 *$ & 1.242 \\
\hline High importance attribution & $2.164 *$ & 1.227 \\
\hline \multicolumn{3}{|l|}{ Cooperation with foreign research institutions } \\
\hline Medium importance attribution & $2.157 *$ & 1.361 \\
\hline High importance attribution & $3.732 *$ & 0.756 \\
\hline \multicolumn{3}{|l|}{ Cooperation with domestic firms } \\
\hline Medium importance attribution & $2.161 *$ & $1.515 * *$ \\
\hline High importance attribution & $3.731 *$ & $1.731 * *$ \\
\hline \multicolumn{3}{|l|}{ Cooperation with foreign firms } \\
\hline Medium importance attribution & 1.508 & 1.592 \\
\hline High importance attribution & 0.793 & 0.698 \\
\hline \multicolumn{3}{|l|}{ Geographic regions } \\
\hline South & $0.265^{*}$ & $0.605^{*}$ \\
\hline Northeast & $0.416^{*}$ & 0.944 \\
\hline North & $0.137 *$ & 0.885 \\
\hline Midwest & $0.178 *$ & 0.791 \\
\hline Science Index & $1.352^{*}$ & $1.257 * *$ \\
\hline Technology Index & 1.013 & 0.866 \\
\hline Constant & 0.822 & $2.247 *$ \\
\hline Observações & 949 & 1083 \\
\hline LR (qui-quadrado) & 418.74 & 117.42 \\
\hline Prob $>$ qui-quadrado & 0.00 & 0.00 \\
\hline Pseudo-R ${ }^{2}$ & 0.319 & 0.084 \\
\hline
\end{tabular}

Source: Authors' own elaboration. 